\title{
Article
}

\section{Intricacies of Moral Geographies of Land Restitution in Estonia}

\author{
Anu Printsmann * (D), Raili Nugin $(\mathbb{D})$ and Hannes Palang (1) \\ Centre for Landscape and Culture, School of Humanities, Tallinn University, 10120 Tallinn, Estonia; \\ raili.nugin@tlu.ee (R.N.); hannes.palang@tlu.ee (H.P.) \\ * Correspondence: anu.printsmann@tlu.ee
}

\section{check for}

updates

Citation: Printsmann, A.; Nugin, R.; Palang, H. Intricacies of Moral Geographies of Land Restitution in Estonia. Land 2022, 11, 235. https:// doi.org/10.3390/land11020235

Academic Editor: Hossein Azadi

Received: 31 December 2021

Accepted: 31 January 2022

Published: 4 February 2022

Publisher's Note: MDPI stays neutral with regard to jurisdictional claims in published maps and institutional affiliations.

Copyright: (C) 2022 by the authors. Licensee MDPI, Basel, Switzerland. This article is an open access article distributed under the terms and conditions of the Creative Commons Attribution (CC BY) license (https:// creativecommons.org/licenses/by/ $4.0 /)$.

\begin{abstract}
This article employs moral geographies in analysing the land restitution process and outcome. Moral geographies investigate how abstract values, deliberations and judgements are translated into everyday life and, consequently, to landscape. The dynamics of moral geographies are analysed by transdisciplinary research methods using mainly qualitative data, such as documents, media and literature, but also spatial and statistical data. Land restitution in Estonia had its start in 1991, instigated by the heat of national reawakening, aiming to reverse the past 50 years of Soviet 'wrongdoings'. This task proved to be not so straightforward. The initial heydays got entangled not only in all subsequent matters of practicalities, but also with social and spatial justice. To date, land reform has been completed on 99\% of Estonia's territory. For over 30 years, the land restitution has been shaped by global changes as well as local particularities and, in the process, moral ideas have been transformed. Thus, though landscape reflects moral categories and ideology, these two are interdependent: landscape can, in turn, mould moral ideals in certain ways.
\end{abstract}

Keywords: property; landscape; identity; ideology; legislation; justice; land use

\section{Introduction}

With the widest imaginable brush, both bold and colourful, the Estonian national myth of origin would go something like this: ancestors settled in the territory just after the continental ice had retreated over 10,000 years ago, making Estonians one of the most sedentary peoples in Europe. Whereas archaeological findings do date the first settlement and burial sites back to 9000 BC, the archaeological, anthropological and genetic evidence show several waves of immigration from different points of origin, indicating that the persistent ethnos did not emerge until the Iron Age (6th century BC). Despite hints that the ethnonym might be dated back to the $\mathrm{BC}$ era, the people themselves used the notion of maarahvas - 'the folk of the land'. The word maa in Estonian means land, country, (E)arth, ground, soil, terra, territory, countryside and rural area; rahvas - ethnos, people, folk, nation. The name 'Estonians' was not officially proposed until 1857 and it caught on with the national awakening at the end of the 19th century. The persistence of the word 'land' in naming the entire nation explains the importance of land in the Estonian national psyche. However, in this, of course, Estonians are not alone [1-5].

Land, landscape and language are important from the perspective of Estonian national identity, and all these notions form in themselves an excellent soil in creating several myths about the national past and psyche [6]. A common construction about Estonian identity depicts Estonians as a rather individualistic people, citing as explanation a sparse settlement pattern throughout history, when a common peasant could see only a neighbour's (chimney's) smoke and not more. Yet research into historical maps places the dissolution of dense villages only into the land consolidation era of the 19th century [7]. This belief in 'solitary nature' is an interesting construction of both the past and the role of landscape and place-making in it.

Such ideologically loaded myths about land and secludedness were often behind the restitution processes in many post-socialist countries after the collapse of the Soviet 
system. The Communist past was seen as an intrusion into individualism, and collective farms were perceived as an outcome of the repressive Soviet system. Most Central and Eastern European countries, except for Hungary and Poland, have engaged in some form of restitution of land rights to former owners. The Czech Republic, Slovakia, Poland and Slovenia did not expropriate all agricultural land during the Communist era, re-established the ownership rights of individuals whose land had not been expropriated, and also restituted a much smaller portion of land that had been held by the state. Poland and Slovenia continued to operate small private farms during Communist rule. Estonia, Latvia, Lithuania, Romania and Bulgaria restituted land to former owners only. Most of those who received land though restitution did not farm the land returned to them (i.e., did not work on the collectives farming it). Each of these countries faced a unique set of problems related to restitution. All in all, the restitution process in many countries has not resulted in smaller, viable family farms [8,9] (pp. 21-46). Estonia has been considered the strictest in applying restitution with the fewest restrictive measures and a low tolerance for sustaining existing economic forms [9] (p. 2).

Restitution entails a certain dimension of moral justice-what has been taken away, needs to be given back - to reverse Soviet 'wrongdoings'. In Estonia, after the dissolution of the Union of Soviet Socialist Republics (USSR), it was believed that restitution should include everybody and be enforced as soon as possible. The 50 years of Soviet rule had made the determination of who is this 'everyone' and what they had, problematic to prove. Among many other issues, it raised the question about what happens to those who have been inhabiting the land in the meantime? Land restitution in Estonia grew in the complexities of moral concerns, as well as in the practicalities of the actual process. While nationalisation of the land into kolkhozes and sovkhozes in the 1940s has been documented rather well [10-13], dissolution in the 30-year period of land restitution has not. The Estonian Research Information System has only 11 English references with 'restitution', e.g., [14], the majority from the viewpoints of public administration, legal disputes and housing issues, e.g., [15], with excursions into how restitution has influenced folkloristics, e.g., $[16,17]$. This article is an attempt to fill the gap.

First, we give a brief overview as to why there was a need for land restitution, then follow up with a theoretical framing of moral geographies of land. After that, we exemplify how the moral and ideological values that triggered the process of restitution stumbled upon numerous obstacles in legislation, as well as everyday practices. This part of the article is based mainly on parliamentary minutes from 1990 to 1995 and illustrated with interviews from museum archives. We show how the euphoria was soon replaced by disillusionment, with examples from diverse sources (media, literature). After these rather emotional excursions, we introduce 'hard facts' and show how the process of restitution-an example of how moral geographies operate-has affected landscape, agricultural production and borders.

\section{Brief History}

The roots of current land restitution go back to the 19th century (see [18] for path dependency and landscape inertia), when the first pillar of the current land use pattern was formed [7]. Back then, Estonia was part of czarist Russia, with Baltic German landlords as the predominant ruling elite. Until the beginning of the 19th century, Estonian land use was feudal. In 1816/1819, however, serfdom was abolished, with peasants obtaining increasingly more rights. Baltic Germans started to sell land to them as property even before the so-called Peasants' Laws of $1849 / 1856$, by dividing formerly common lands into separate plots. The buyers were not always the people who had used the land before, but rather those who could afford it. Hence, this property reform also served as a mechanism for stirring up the population and the established settlement pattern. This process took a rather slow start in the middle of the 19th century but speeded up in accordance with the national awakening of the following decades. Together with population growth and cumulative personal freedoms, the desire for acquiring a piece of land for property was 
overwhelming. When selling land, the landlord had to divide the commons into separate units, ensuring that quality was as equal as possible in terms of arable land, pastures and forests, that a unit should not have lands in separate locations, and that there would be minimal need to move buildings. Usually, a farm formed one contiguous whole, but there were still cases in which a farm might have plots of hay meadow or forest quite far away. The property borders created during this period have largely lasted, with some modifications, until today (Figure 1).

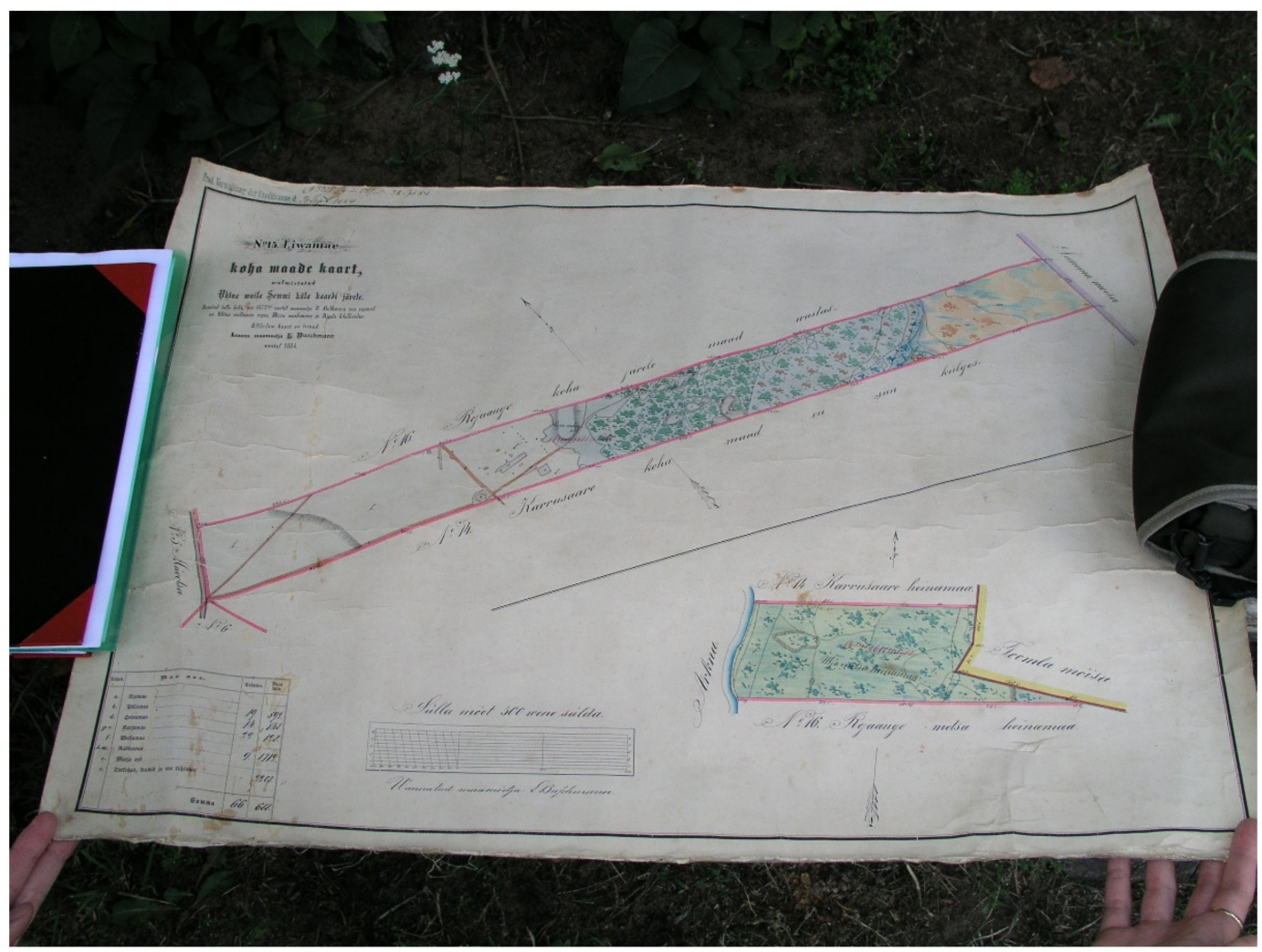

Figure 1. A keepsake: hand-coloured map of a farm from 1872/1884 presented during fieldwork. Sämi-Tagaküla village, Rakvere municipality, Lääne-Viru county (photo: Anu Printsmann 2007).

The second pillar upon which land ownership in Estonia rests today was created in the 1920s. By 1918, when Estonia declared independence from Russia, the population in the Estonian territory (appr. 45,000 $\mathrm{km}^{2}$ ) was roughly one million [19], with over 1000 manors with an average size of over 2000 ha and 75,000 farms, out of which 50,000 were privately owned plots of 30-60 ha [20]. Still, the shortage of land was rather great, as many who wanted to cultivate their own land did not own it. One of the priorities of the new state was to introduce land reform in 1919. According to this reform, the majority of the land (with a few exceptions) was taken away from the mostly German-speaking landlords (Baltic German elite) in order to divide it among mainly Estonian-speaking peasants. When, after the declaration of independence in 1918, a war with Russian and German armed forces broke out (known in Estonian history as the War of Independence, 1918-1920), the Estonian government promised land to anyone who would fight for the newly established state. After the war, from 1920 onwards, the lands confiscated from landlords were given to over 56,000 war heroes and the landless, among others. Applicants had to prove their willingness to cultivate the land, the state helping with loans and other measures. By 1939, the number of farms had risen to 140,000, with an average size of 20 ha [13].

After WWII had broken out, Estonia was occupied by Soviet troops and, in 1940, was incorporated into the USSR. In Soviet Estonia, all land was nationalised. However, in 1941, when Germany occupied Estonia, the Nazis returned the land, to be nationalised once 
again by the Soviets in 1944 [10,11]. Initially, the former owners were allowed to continue using the nationalised land 'forever', but the pressure to join collective farms strengthened step by step after the war [10,12]. During the first short period of the occupation, in 1941, 10,000 people (mostly members of municipal and political elites) were deported to Siberia, contributing to creating an atmosphere of fear. After the war, when Soviet powers realised that the collectivisation process was too slow, another deportation campaign followed in 1949. This time, over 20,000 people were deported, eradicating the class of well-to-do farmers with their families. Their farms and lands were confiscated and, in many cases, new inhabitants moved into their houses. By 1950, most Estonian agriculture was collectivised. The remaining farmers joined the collective farms with their equipment and livestock, as well as the land they used. Although, for the most part, small yards around the living quarters remained available for private use, generally the former property borders were abolished, and legally the system started from scratch. However, former borders were still remembered to some extent [21] and followed in customary practices such as berry-picking in one's 'own' forest [22], but without legal implications.

Maandi [21] (pp. 454-455) has concluded that:

... people who owned land before the Soviet occupation kept track of the officially annulled pre-Soviet land rights, by relating to inertial landscape elements as memory-aids (Figure 2). To local inhabitants the landscape, in which past and present structures always merge, provided substantial evidence in support of the idea of legal continuity of pre-Soviet land rights. Hence, the post-Soviet land restitution reform often implied a re-discovery or re-expression of property rights that had been silenced, but not lost.

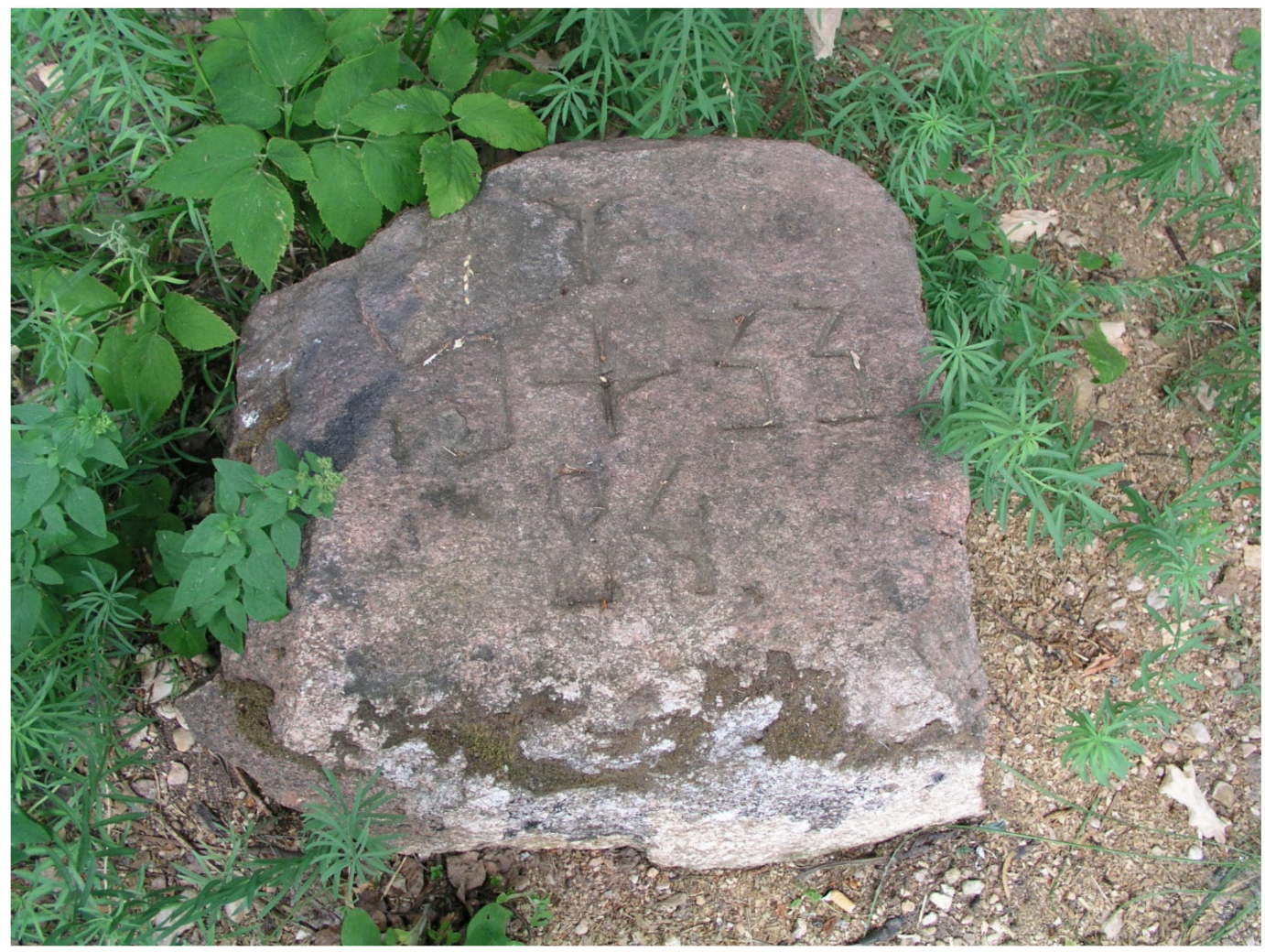

Figure 2. A bordermark in Tsirgumäe village, Valga municipality, Valga county (photo: Anu Printsmann 2005).

People who survived Siberia were slowly allowed to move back after 1956, but with no properties returned and returnees sometimes forbidden to settle near their former homes. Further distrust was forced on society by uprooting and stirring people around, ruining meaningful ties with community and land; for example, by allocating ${ }^{1}$ young 
graduates away from home to work in different rural areas. Previously, the 'the folk of the land' had been rather sedentary in their parishes until the beginning of the 20th century. With industrialisation, urbanisation and mass immigration from all over the USSR, this sedentarism was disrupted. This feeling of disruption in rural areas was further deepened by the building of central collective farm villages, with blocks of apartments and disproportionate office and cultural houses, whose architectural design was intended to blur the borders between the urban and the rural $[23,24]$. It has been argued that the sense of place attachment in those semiurban villages was weaker than in traditional villages with scattered farmhouses [25].

The regime of the Soviet Union started to change in the late 1980s, together with the realisation that collective agriculture was unable to feed the country. First, whilst still in the Soviet legal system, the Estonian Soviet Socialist Republic Farm Act [26] was passed on 6 December 1989 and entered into force on 25 December 1989. This act allowed the private use of agricultural land in larger quantities, in short, a sort of private farming. This cannot be called restitution, as the created units were considered new in legal terms, and the land remained state property. In fact, very often those who used this opportunity were people who remembered private farming or were their heirs, and sometimes these claimed lands coincided with pre-Soviet properties.

Restitution, in legal terms, became possible only after Estonia had become independent again on 20 August 1991. As preparations had started earlier, the necessary reforms followed quickly: the Land Reform Act [27] was passed on 17 October 1991 and entered into force on 1 November 1991. The initial aim was simple-return properties to those who had owned them as of 16 June 1940, before the country was taken over by the Soviets. The objective of land reform (as part of more general ownership reform) in § 2 [27] stipulates: 'Based on the continuity of rights of former owners and the interests of current land users that are protected by law, and to establish preconditions for more effective use of land, the objective of land reform is to transform relations based on state ownership of land into relations primarily based on private ownership of land'. The main purpose of land reform was to remedy the injustice caused by the Soviet occupation in 1940, when all land was nationalised, and private ownership of land forbidden [28].

The first restitution of three separate plots was conducted on 12 December 1992, in the village of Reopalu, Väätsa municipality, Järva county. Two of them were later divided; one remains in the same form. Further instances occurred in 1993 [29].

How the overall process progressed and became enmired in intricacies, is discussed later in this paper.

\section{Moral Geographies of Land}

We often seem to ignore the possibility that ethical and moral categories can have a spatial dimension, and thus be analysed in the framework of geography. The concept of moral geography is not new: it was defined in the 19th century. For example, one phenomenon that moral geographies study is the extent to which the distance between people affects how they are treated. Those closest to us geographically also tend to be the ones with whom we share values and feel close to emotionally, though this can create and reproduce inequalities [30]. Yet, people very 'close' to us may be geographically far away, especially now in teleworking times. According to liberal values, we should try to stay unbiased [31].

However, Aristotle pointed out that there are two types of laws: the laws of nature that are universal, and the laws created by humans, applicable to certain regions, including customary laws [32]. Moral norms change both in time and space, even if such norms have become prevalent in larger territories. What is moral is culture-dependent-what is considered good or bad, just or unjust [31]. One of the most common definitions of morality is that it refers to particular traditions and habits, prescriptions and practices shared within specific groups without deeply questioning them [33]. In short, moral geographies study the 
interrelatedness of moral frameworks within temporal-geographical settings, e.g., how some types of behaviour, or particular kinds of people, are considered right or wrong [34] (p. 478).

Moral geography is not precisely a field of study within geography, it is rather a mindset for analysing relationships between societies or their (vulnerable) subgroups and their operations in the spatial realm [35] (see also [9] (pp. 47-64)). It has never been a mainstream topic in geography, but quietly emerging, here and there, across decades [36-39], finding a way even to the title of an Association of American Geographers presidential address [40].

In its early days, moral geography was mainly connected to the urban context [34]. Its main objects were social justice and environmental ethics, intertwined with questions of moral norms. While there is a strand that focusses on the individual as a spatial moral subject, in this paper we are more interested in socio-spatial dialectics. In the former 'prescriptive' case, subjective moral growth in the inherently geographical nature of moral actions is important, and can be framed in the paradigm of humanistic geography-the questions about being human [41-47]. However, in the latter, the moral is 'nonprescriptive' - it is connected to societal decisions and practices related to power, one way or the other [48-50]. Hegemonic discourses about how to evaluate and judge a space and actions within that space are the main issues [51].

Throughout history, politics and policies have shaped geographical borders by dividing and conquering lands, imposing their morals and laws on them. Today, when globalisation is in full swing, there are more sophisticated methods for imposing values across different territories than by conquering (or dividing) them. Nevertheless, national governments have also preserved a powerful mandate in establishing, maintaining or shaping norms, moral values and laws that continue to mould landscapes and geographies [52] (p. 250). This is rather common in establishing regional or agricultural policies. For instance, Opie [52] (p. 241) demonstrated that certain forms of agricultural production, such as family farm management, have received federal protection in the US, justified in terms of " good" human values and "authentic" environmental conditions'. Opie [52] (p. 242) suggests that 'Moral geography takes hold when government policy identifies a geographical landscape and its inhabitants in need and deliberately responds to save that region'.

Though legislative decisions are always intertwined with moral and ideological grounds, sometimes establishing specific principles means manoeuvring in moral minefields. Returning something (e.g., land) within restitution entails such a hazard since it must establish the borders of 'right' and 'wrong', redistributing something that has changed ownership, distinguishing those who are worthy (of owning land) and those who are not (compared to [5] the use of fertile soils in a land-based capitalist economy). The (re)creation and (re)production of inequalities is inevitable in such cases, even if the decisions are justified on moral grounds shared by society. As Feldman [53] (p. 165) has pointed out, ownership and land use can entail fundamental contradictions, affecting issues of ethnicity, citizenship and moral entitlement.

In this article, we rely on the postulate that landscapes are produced not only by the people who live in their surroundings, but also socially via moral and ideological guidelines and hegemonic discourses [54]. Landscape is as much a source of social negotiations as legislative practices. Land and its meaning are deeply rooted in questions of (national) identity, feelings of belonging and place attachment but, at the same time, become mingled with legal practicalities [54]. We believe that studying the interactions of moral aspects within certain geographical phenomena (such as land property and use, landscapes, and bordering processes in landscape) is a fruitful way to understand the dynamics of identities and ideologies and their intertwinement. Because the majority of Estonians or their relatives have dealt with the restitution process, it has created a shared generational experience.

\section{Land Restitution Process}

Moral geographies intertwine moral values with political and/or spatial decisions [52,55]. Morally reasoned decisions that affect everyday lives through spatial organisation and 
landscape are especially topical during periods of restitution, as a new inherent, and later unquestioned, code of conduct is established. Who gets back what land and how this is justified are highly ideological issues. Often, when these decisions are negotiated in daily practices, several discrepancies emerge and need to be dealt with on both the practical and the legal level. In the following, we give an overview of some of these hubs that emerged during these negotiations (Figure 3).

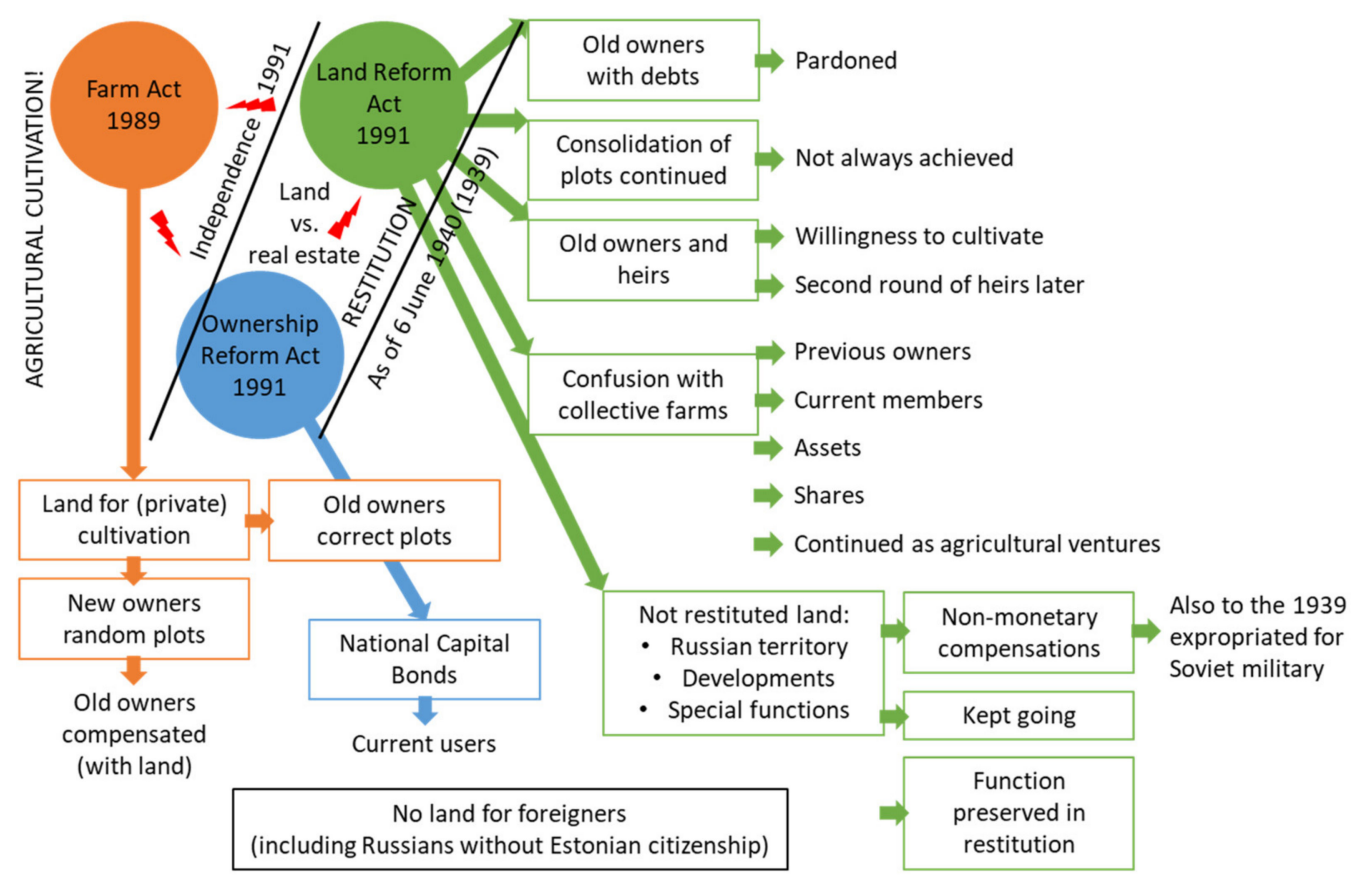

Figure 3. Scheme of the main intricacies of the land restitution process.

The first subsection is based on discussions in the Parliament of Estonia in 1990-1995². This era is significant because it covers debates before the regaining of independence (1991) as well as after, involving the most intensive years of legislative uncertainties in Estonia. This is followed by illustrations of how these legal pirouettes affected the lives and experiences of actual people, and how these changes are represented in cultural texts.

\subsection{Parliamentary Debates}

In 1990, the reason for legal insecurity was predominantly Estonia's status-it was still a part of the USSR and thus had to operate within its legislative borders. At the same time, the goal had been set to start privatising properties, industries and land, and begin restitution of assets that had been nationalised or requisitioned during the Soviet period. As Prime Minister Edgar Savisaar pointed out in 1990, the transition period was mainly characterised by an 'unclear political state, the need to be always ready to change tactics and make corrections in our economical political behaviour' (Savisaar, 4 June 1990).

The Farm Act [26] (25 December 1989) was adopted when Estonia was still under Soviet jurisdiction. According to this law, the land was distributed to those eager to cultivate it. The responsible distributors were local governments with no detailed knowledge about pre-WWII circumstances. Thus, the distribution of land under the Farm Act conflicted with the Republic of Estonia Principles of Ownership Reform Act [56] (1991) and the Land Reform Act (1991) that were under discussion in Parliament at the time this land distribution took place. After several municipalities had to deal with such discrepancies, it was decided that the land acquired under the auspices of the Farm Act was not to be returned to previous owners but compensated with another piece of land somewhere else. Therefore, at one point, the distribution of land under the Farm Act ceased before the law was actually abolished (Kama, 9 October 1991) on 17 October 1991. 
The Land Reform Act [27] (1 November 1991), which would settle questions about who had the right to get land back, to buy it and to own it, was designed to be the base for many other laws dealing with agriculture, ownership and land organisation (Tamm, 23 May 1990).

In the years of political transformation, ideological sentiments ran high in the parliamentary discussions conveying the contemporary yearning for righteousness with their sententious vocabulary. Land restitution discussions involved a number of slogans and thus were quite blurry in setting forth particular steps supposed to be taken in the near future. Land was defined as a 'national resource', possessing special value. The Estonian inter-war republic (1918-1940) served as a sort of moral compass, its decisions used to justify arguments in the contemporary political world, and the routes taken by the interwar republic were not openly contested. At first, the overall model of development and direction for Estonian agriculture was taken precisely from that period and had the small-scale family farm at its core. This idyllic and romanticised idea of a small (family) farm providing food for its nation is not anything uniquely Estonian, having been an ideological model in several countries throughout history [52]. Land and its agricultural cultivation were part of the loaded national ideal; therefore, its selling for the purpose of making a profit was disdained and labelled as speculation. Land was not supposed to be treated like any property; it was a particular capital, and the state had to ensure that land was distributed (and returned) only to those who would actually start farming it. It was stressed that the state should also create a possibility to acquire land for anyone who wanted to cultivate it (Lind, 19 June 1990), as the applicant had to prove their willingness to work the land in the 1920s to be worthy of the 'prize'.

It was quite clear from the beginning that there was land that, for several reasons, could not be returned, such as areas now in the Russian territory or industrial and urban developments. For instance, there were land units which functioned for production or research purposes, and their privatisation and/or redistribution to different owners would potentially stop these functions (Lind, 23 October 1990). The Land Reform Act, though creating a stricter base for restitution and diminishing the municipality's role in deciding which land was returned, also enabled declining the return of some types of land. It was, however, suggested in 1993 that under some conditions it would be possible to return land if the previous owner promised to preserve the current land functions (e.g., a park) (Käärma, 20 October 1993).

One of the problems was the uncertainty about the status of the land. It turned out there were no good mechanisms to detect in the 1990s if the heirs to the land existed or had claims to it (Kama, 9 October 1991). Initially, the decision about which properties and plots were to be returned was the competence of local government. According to the Farm Act, then, before returning land to the previous owner or to someone who wanted to cultivate it, the municipality had to consult the current user and obtain their coordinating decision about the act of restitution. The law put no obligation to return the land to the owner in the very place the previous owner had owned, rather it could be compensated by other means, such as another piece of land somewhere else.

The question of compensation posed another set of complicated problems. The Minister of Agriculture, Väino Lind, stressed in his speech in 1990 that any nonfinancial forms of compensation would be better, with the state also preferring the deferral of compensation to a longer period, if possible. This was needed not only because the state lacked funds, but also because in 1990 the monetary unit used in Estonia was the Soviet rouble, the value of which diminished with inflation within days, if not hours. Estonia intended to introduce its own currency soon (it was introduced in 20-22 June 1992). Initially, Minister Lind hoped that compensation would involve only the part of the land the previous owner actually owned, as well as the proportion of investments (e.g., melioration). Thus, according to him, the state would not have to compensate the part they had still owed to banks. As it occurred to be too complicated to determine the debts and investments, this aim was later abandoned. 
Restitution also applied to lands that were forcefully expropriated from landowners by the state in the autumn of 1939, when some land was given for establishing Soviet military bases following the USSR's ultimatum to Estonia resulting from the Non-Aggression Pact between Nazi Germany and the Soviet Union, whose secret protocol delimited 'spheres of interest'. However, the previous landowners had received compensation from the Estonian state. Now, the question of compensation was discussed again, and that raised several questions (Fjuk, 24 November 1993). The Minister of Reforms, Liia Hänni (24 November 1993), explained that, indeed, the government had paid for 601 farms in 1939. However, as the Nazi German occupation (1941-1944) followed soon after, the times were uncertain and the documents for 501 farms had not been formalised, and thus the logical conclusion would be also that the owners of these farms had not yet received compensation. The archival data for these transactions had been poorly preserved. In addition, even if some people had received the compensation, they would have deposited the money in the bank. Since the banks had been nationalised during the Soviet era, the money was irretrievably lost. Therefore, Hänni proposed, it would be wiser to drop the subject altogether and give compensation to all those whose land had been expropriated.

Obviously, the restitution process would bring forth social injustice because returning the land (and properties) would potentially be unfair to those inhabitants who had been living on these lands and in the houses during the 50 years of the Soviet regime. The issue of justice emerged not only on the axis of previous/current owner, but among groups of previous owners, too. For example, just before Soviet rule was forcefully established in Estonia in 1940, only 15-20\% of individual farms were debt-free and actually owned their farmland. By the time the Ownership Reform Act [56] was passed on 13 June 1991 (adopted 20 June 1991), it was clear that finding out who owed how much to the banks or to the state would be too complicated and take too much time, thus inhibiting reforms. Therefore, it was decided that ownership reform should not take into account any debts that were tied to property, just as money that was in bank accounts was not to subject to restitution. The initial version of the land reform, however, took into account land redemption debts, i.e., only the redeemed part of the land had to be returned. That, of course, created much tension and feelings that justice was being violated. Thus, eventually this aim was dropped in the frame of land reform, as the archival bank documents were hard to retrieve and finding out the debt balance would hinder reform (Kama, 7 April 1993).

To add to the confusion, ownership of state property and collective farms (kolkhozes and sovkhozes) was also blurred. Kolkhozes, by definition, were farms where farmers had given up their land for the collective good, thereby becoming members of the kolkhoz. Legally, they used collectively all the land within the kolkhoz borders and owned collectively all the properties that belonged to it (at least on the paper). A sovkhoz was a farm belonging to the state. However, during the process of merging collective farms throughout the Soviet era, several kolkhozes and sovkhozes joined. It was impossible to determine which collective farm belonged to the state and to what extent it eventually belonged to the members of the kolkhoz (Pajo, 14 January 1992). Things were more complicated by the fact that several agricultural ventures owed money to the state, and that aggravated the overall goal of privatisation. The collective farms were gradually dissolved, but the distribution of their assets was quite a challenge, as these were distributed both to current members as well as previous owners. It was established, for instance, that family farm animals would be returned during restitution/distributed to kolkhoz members only if the (previous or future) owner or their heir had conditions to continue animal husbandry or to start it (Pajo, 14 January 1992). Production facilities were supposed to be returned/distributed only in case that agricultural use continued. Commonly, the collective farms were reorganised to become collective economic units, whose members were workers, former workers/pensioners, farmers and elected administrative personnel whose last employment had been at the previous kolkhoz/sovkhoz. In some cases, large farming facilities were not to be dissolved and, thus, had to be managed collectively. Those who did not want to take part were compensated with shares (Pajo, 14 January 1992). Though this idea of 
distributing kolkhoz assets to members looked good on paper, it caused several conflicts and injustices. Assets were not really distributed to everyone. During the hyperinflation in 1990-1991 and, on vague legal grounds, only few people received the assets and the rest were compensated with questionable amounts of money or obligations. ${ }^{3}$

Yet another issue discussed in the 1990s was the dividing of farmlands if they were to be returned to different heirs. The idea that land should be cultivated was so strong that it was also established that if land is inherited by multiple siblings, preference should be given to the one who would potentially cultivate it (Varul, 26 April 1995). The underlying idea was that the farms should preserve their integrity so as to be able to produce critical amounts of agricultural products and to prevent selling land for profit. Here, too, the interwar republic era was brought up as an example, when land was firstly rented and sold only after it was clear that the tenant would cultivate it appropriately.

However, some land that was subject to restitution had been cultivated in unconsolidated plots back in the interwar period. Now, to ensure the effective cultivation of arable land, these 'slices' did not make much sense. It was suggested that they should be merged and changed to bigger plots (Hänni, 28 September 1994). This was not always achieved.

The restitution processes (providing archival proof of one's ownership or inheritance, establishing if the owner exists, finding out who has claims to collective farms, etc.) took time, and agricultural development was hampered and stagnant until these legal obstacles were to be solved. A Member of Parliament, Krista Kilvet (7 December 1992), pointed out that prioritising ownership relations over economic development could be disastrous to rural agriculture. She asked rhetorically, 'What can we say to the farmers? That they have all got it wrong so far and their work is worthless and we don't need them?'. She went on to say that it is immoral to keep farmers in ignorance and to tell them that perhaps they can still rent land they are cultivating, but maybe someone will come and take it away. Particularly, if that someone is not their neighbour, but someone from Sweden or the Estonian capital city of Tallinn, someone the farmer has never met and with whom they have nothing in common. She stressed yet again that land should be given to those who are able to cultivate it, with previous owners given some sort of a compensation. She warned against creating a new injustice. Her arguments were backed by Rein Veidemann (7 December 1992), who accused Parliament of dealing with questions that have little or nothing to do with everyday mundane matters. In his view, rural life had held Estonianness together for a long time, and that neither land nor ownership reforms had taken into account the realities of it. Now, according to him, this Estonianness was under threat together with the Estonian countryside. There were, however, also less emotional MPs who suggested that one can, of course, talk about justice and rights, but stated that there is no such category as justice in economics. Kalev Kukk (12 January 1993) insisted that if Estonia wanted to achieve some results with the reforms, then Parliament should accept that there can be no ownership and land reform outside economic decisions, and that these things should be looked at in a more complex way. In any case, the reforms were hindered due to several juridical disputes. Some voices called for not broadening owners' circles to more heirs so that the process could become smoother; there were also suggestions to simplify the process (Fjuk, 6 May 1993).

Throughout the period under scrutiny, several members of Parliament were concerned about how reform was proceeding, voicing fears that dealing with too many juridical nuances would be fatal to agriculture and economic development (e.g., Raig, 14 December 1994). For instance, in order to restitute land, it had to be measured by a professional land surveyor (with a special licence). Yet, these specialists were in great demand and there were not enough of them, particularly in rural areas. That also meant that legal documents certifying ownership were delayed. Thus, owners could not get loans from banks, rent the land or conduct any other legal operations connected to land ownership (Arro, 23 May 1995). In addition, there was a question about the accuracy of maps, not only those being used for returning land, but also current maps used for delimiting farmland boundaries (Hänni, 18 October 1995). 
The main problem with creating justice within these reforms was that they contradicted each other. The Ownership Reform Act had established that inheritance was eligible only within one round of descending relatives. The Land Reform Act had defined the round of heirs to a broader extent. This created a situation where land was returned to the second-round relatives, yet the buildings on it were not (Tamm, 12 January 1993). Thus, a two-fold problem emerged: on the one hand, the building's owner could not develop a well-functioning farming as they did not have enough land for cultivation, whilst the land's owner had to start building new houses, thus spending much of the capital they could have invested in agriculture into buildings they could inherit. Later, this discrepancy was abolished and both reforms broadened the inheritance circle.

The fact that land held an ideological value besides an economic one was illustrated by legislation that prohibited selling arable land to foreigners. In addition, foreigners could not buy plots for summer cottages by the sea. This decision reflected not only the differentiation between foreigners and Estonians, but also referred to borders within the state, since a share of the Russian-speaking population did not have Estonian citizenship and thus were considered 'foreigners' by the same law. This created divisions within society.

In general, the overall process of restitution became entangled in different questions emerging after every new decision was taken, triggering numerous practical obstacles that needed to be solved. Subsequent sections show how these intricacies affected the actual lives of the people involved in the process.

\subsection{Processing Experiences}

In this subsection, we introduce case studies, exemplifying how these unclear and contradictory regulations were negotiated at the micro-level individually, characterising the absurdities of the time. The cases are from two different angles: officials working with legislation dealing with restitution, and a previous chairperson of a collective farm.

Our first example of everyday practices comes from Ene Rebane (born 1968), a clerk working in a municipal government, and later at the Ministry of Justice. Her perspective illustrates how the confusion initiated by restitution reforms also overwhelmed municipal and governmental institutions which had to implement them. Ene recalled that the process was complicated not only by vague legal foundations, but also that the legislative shift was sudden and the time windows for applications were tiny, so that municipal offices were not properly prepared to tackle with these issues:

When we started to deal with applications, the municipality did not have special rooms for client service. We had regular office rooms, corridors, halls, where people had to wait and it was quite tough for them. But also for those, who dealt with applications /... /. We had some application forms that we had to fill in by hand, and we did not have any copy machines for copying, but just some pre-filled-in forms, which were copied by hand, using a special tracing paper, to make several copies. The entire process was rather time consuming and exhausting. People were drained ... (Estonian National Museum Archive, ERM V 882:4).

She described that one of her emotionally hardest memories dates back to this time, when one of clients who had been waiting in these corridors (perhaps also stressed by the entire restitution process) had a heart failure in a hall and died there. According to Ene, he had been quite young, in his forties, and despite her colleague's attempts to provide first aid, he did not make it. The metaphors of how the restitution process has literally taken many lives have been used in different media articles. Due to the injustices it created, it has even been compared to genocide, claiming it was worse than Stalin's deportations [57].

Ene also narrated that that people were not familiar with the process' legal details, and so sometimes found themselves in trouble. She exemplified this with a court case. Someone had to prove that, when applying for the restitution of a house, they had also intended to reacquire the land under (and surrounding) it. For a person who had been living under Soviet rule, land as an object of real estate was meaningless. 'A building as such was an 
asset, not the land under it; it had belonged to the state all the time and people did not pay attention to it'.

Due to changing legal frames, court disputes were common and sometimes still continue, but there were also many jurisdictional irregularities. Several archive documents also surfaced after some restitution decisions had already been taken, causing clashes (see [9]).

Ene's recollections about her time in the Ministry of Justice illustrate how fragile the system had been. As legislation had to be built anew, some fields of society were totally unregulated, and gaps emerged that needed urgent responses. Discrepancies in everyday situations pointed out the lack of legal regulations. The legislative system had to react to these critical deficiencies rather than create laws in a systematic way. Sometimes, courts pointed out conflicts in legal matters and the ministry had to react quickly to remove these inconsistencies. At other times, the government had to issue regulations on matters that, according to the constitution, had to be regulated by laws passed by Parliament.

This legal disarray meant that the existing laws were changed over and over. The Land Reform Act, for example, was redacted altogether 53 times, gaining four redactions during 1994 alone. To keep up with these changes, Ene spoke about how she and her colleagues used scissors and glue to compile existing versions of laws, integrating the changed parts into the printed laws. As the practice of changing the laws and regulations had become quite common, the laws began to be issued in file binders, where you could add new pages and remove the old ones. This practice did not last very long, as computers took over.

Alo Kotka [29] shared that technological leaps also affected the land restitution process with the issues of spatial data availability. Maps had a special status in the Soviet regime. They were designated only for official use, produced in local coordinate systems and often distorted to mislead the enemy (see [58]). Estonia created its own cartographical systems and, in the 1990s, started to use Geographic Information Systems (GIS). The first maps were stored on magnetic tapes in the basement of the Estonian Land Board, with no devices to read them now. The first vector data were produced in 1998. Due to isostatic land rise the area of Estonia is expanding and contemporary measurements are evolving. Hence, exact plot sizes must be adjusted. This came as a big surprise for wider audiences, when letters with changed areas and higher land taxes were issued.

The perspective of a person in power was confusing as well. Tammi Ansper (born 1941) was a kolkhoz chairman at the start of the turbulent time of transformations. During his tenure, the Farm Act was introduced. As mentioned above, in 1989 all the land still belonged to the state, but the law enabled distribution for cultivation and usage. According to Tammi, many of those who started to keep farms were actually the ones who wanted to restore their family's farm that had been taken away during the deportations:

At that time, old farm masters were still alive, they remembered their cattle and where their land had been /... / and finally there was a time when people who wanted, got their farm back. /... / We gave everything back, we found new living spaces for the ones who had been living in the houses in the meantime. I dealt with it as chair of the kolkhoz (Estonian National Museum Archive, ERM V 882:6).

If those living inside those houses had invested in their living quarters, they were compensated for the cost of building materials.

The Farm Act also allowed establishing new farms. Tammi admitted, ' ... well, of course, there was a lot of fuss around it afterwards ...' as some of that land that had been allocated later became the object of restitution. According to him, the collective farm simply distributed land without digging deeply into the question of previous ownership. Afterwards, for this land, the old owners had to be compensated, often by giving them an alternative plot. ' ... [H]ectares were hectares, you had to give these back'.

Along with the Farm Act, collective farms were supposed to be reorganised. Tammi recalled that many collective farms were restructured to become agricultural joint ventures, but in his kolkhoz 'everyone started to stand for their own interest...' '. He realised that nothing would come out from a collective venture in his home area. Therefore, he chose to 
start a private business growing flowers. His wife's parents had owned land in another part of Estonia, and she could apply to exchange it for land that surrounded his home, enabling him to build greenhouses for the flowers. Like the time window for applying for land within the framework of the Farm Act, the option for exchanging plots of land was also available for a short period. When the time of restitution came, it appeared that the land Tammi and his wife had exchanged belonged to his neighbour. Luckily, there was some land available farther away that had belonged to the church, which did not apply to regain it. Fortunately, land distribution around his own home did not evoke conflicts. The house he lived in had been built during the Soviet period (in the 1980s) and thus was not an object of restitution.

The collective farm in Tammi's home village collapsed, leaving many unemployed. Though he had applied for the land, his way of coping with the changes was not by starting a farm, but a private enterprise selling flowers. He opened two shops and was a successful small entrepreneur for more than a decade, until his retirement. He did not start a classical farm with cattle and crop fields- the one the discourses in Parliament had advertised as the saviour of the Estonian nation. Paradoxically, as we show in the next section, this saved him, as small-scale farming households turned into dead-ends for many.

\subsection{Representations of Disappointments}

To illustrate the confusion and frustration, the following takes a brief glance at how this was expressed in different cultural fields and by those who tried to cope with the everyday practicalities of land restitution. We demonstrate this disenchantment with examples from contemporary TV broadcasts and fiction.

Dissolving collective farms was uneven in different locations. On the one hand, the old was crumbling and falling apart. On the other, the legal base and local administrations were not quick enough to provide an effective environment for the new. This indecisiveness was also reflected in the media. A broadcast released in 1993 [59] portrayed the lives of the new farmers-those who had started their own farm recently. They were depicted as hard-working and durable people who would not give up on the Estonian rural ideal. Yet, they also described how these prolonged legal processes affected their lives. Kaie, a single mother said:

When there is no law, there is nothing. / . . / [The law] should give security for a farm. / ... / At first, a secure land reform. At the moment I cannot do anything I want, though this land has been given to me to use.

At the same time, when asked why she needs the farm, she answered in the line of the hegemonic narrative of returning to the 'golden' age of the interwar republic, stressing that the farm was her ancestors': 'To live and work and to think about my children's future and work like my forefathers'. The other interviewees in the TV broadcast expressed similar thoughts - they shared the vision of an Estonian rural economy based on farms. Ants, a man who had built his farm in the framework of the Farm Act contrasted those who still believed in kolkhozes to the (new) farmers who 'work with their own heads'. He depicted those who supported the previous order as the ones who are only capable of working when others tell them how. A farmer had to rely on himself alone, as he suggested that one cannot hope for the help of the state: 'You can only rely on yourself and your family. / . . . If you only hope for state help, it doesn't take you far'.

Yet another (new) farmer, Ülo, who also spoke enthusiastically about his farm and the hard work he had put into it, also mentioned insecurities caused by the land reform. According to him, many people around him had applied for land, hoping to sell or rent it, as they were not sure if compensation (instead of restituted land) would be good enough In his words, it depended a lot on the municipality and their decisions about whom to give land to and whom to reject. As Ülo's farm also had its start in the Farm Act, he expressed the ambiguity concerning if he could keep the land or if the state (or the previous owner) would take it back. 
The broadcasts, however, did not concentrate much on legal issues. Rather, they stressed the frugality of the farmers who coped and built up the new Estonia despite hard times. In a broadcast dating back to 1997 [60], Meeli Auväärt, a farmer, was interviewed because she had won recognition for the most beautiful farm. Yet, when asked about her life, she had little positivity to share. Similar to Ants, she said that the only chance to survive is to work hard, as the Estonian state does not provide any kind of help. Though the Land Reform Act had been passed almost six years previously, she still complained about the lack of certainty:

I would need some clarity and perspective. Should we expand or not. Are we [the farmers] needed or all the crops will be imported. The land reform has been prolonged for too much, it's hard to know, what comes, what stays, too many loose ends. It is damn hard right now. It is indeed hard. No perspective, I wouldn't recommend it to [my] children.

The fear that someone would come and take away someone's living was expressed in other broadcasts as well. In a reportage from Noarootsi [61], a region where people of Swedish descent had lived before WWII, an interviewee named Leida said their livelihood was under threat:

I have been here for 50 years and we have built all this up, and repaired and taken care of ... and now they come, all of a sudden and.... /.../ By force, in secret, they fix up the papers and they come now and come, forcefully taking this away.

Just before the end of the WWII, escaping the Soviet invasion, many Swedes fled the country in fear of repression to the country of their ancestors. Their houses remained empty and were occupied by new people such as Leida. Note how in her interview, she depicts the ones aiming to restitute their property as evil, acting in secret and using force. Such a depiction was not rare, as for many it seemed incomprehensible why someone who had lived without the house for half of a century (or, in the case of inheritors, had never lived there), would kick out someone who had lived in it for 50 years.

Another source of confusion and unrighteousness in everyday lives was the dissolution of collective farms. There were no clear rules, and the local administration had to settle this. Without guidance and uncertainty in the legal world, this could become hectic and generate confrontations. This insecure environment is described in detail in a novel published in 1997 by Raivo Männis, entitled 'Tagasiärastaja [Re-embezzler]'. The novel speaks about a former kolkhoz truck driver Villu, who continued to work at a joint-stock association that was formed to handle the machinery the collective farm had owned. One day, when he comes to work, he finds his truck has been stolen. Because the police give little hope of finding his truck and he faces unemployment without it, Villu sets off to recover his stolen machine himself. The novel is built up as a kind of road narrative-he meets several people and goes to different places in Estonia, describing at the same time the chaos and insecurity among the rural people. Especially in situations when Villu enters the rural shops and listens to different conversations, he can feel the overall frustration and even anger for all the reconstruction process:

We outlived the German and Russian government, but not this one. Land tax, social tax, income tax, traffic insurance...

Alimony for living, which is not even enough for dying ... .

Petrol is too expensive. The arable land is uncultivated, full of weed and bush. The state does not buy our crop. / . . / I give my wheat to pigs, but the state imports wheat. The loan interest is 40. The farms were supposed to be freed from tax for five years, but then taxed nevertheless [62] (p. 62).

Driving around and asking about here and there, people suggested his truck could have been stolen by a former ministry worker who had established a farm (in the framework of the Farm Act) nearby. People saw that he had got the best of the assets that were distributed to people during the privatisation process dissolving collective farms. As usual, he learned about him in another rural shop conversation: 
Well, there are smart and successful people in rural areas, too. For instance, this house with a red roof, just some kilometres away from here. Newly built arch hall, new stable and barn. The yard is full of all kinds of machinery.

Oh that. /... / This is a city guy, that's why he is so smart and successful. People say he worked in some kind of ministry.

A crook is he, not a smart one! It's easy to be successful, if you are in such a position, just say a word and everyone brings you what you ask for, no matter whose property, from kolkhoz or sovkhoz [62] (p. 101).

When Villu infiltrated the farm of this ministry official, it turned out there were two people working for him whose ancestors had either owned the house or farmlands and hoped to file a restitution application to get them back. His truck remained lost and there was no happy ending.

The social justice of reforms, uncertain legal matters, changing administrative borders, changing ownership and vague compensation rules may have been interesting intellectual topics to discuss in Parliament, but had a direct and often severe impacts on everyday lives. This created some cleavage between the city and countryside, grudges against those who were successful or got their hands on machinery in the process of privatisation and caused new lines of inequality in rural societies $[9,63,64]$.

\section{The Outcome}

The whole process and outcome of land restitution has been reflected on in the Estonian Land Board commemorative masterpiece of 450 pages [65] on the 30th anniversary of the reform.

In 1991, only 6\% of Estonian inhabitants were against restitution [66] (p. 4), then by 2020 public opinion regarded the principle as necessary but found that the process contained both positive and negative aspects [9] (p. 2, 125-126). More than half of the respondents agreed, in 2020, that ownership reform could not avoid new injustices and the majority of them considered that the state should have paid more attention to the interests of those who had used these properties and land before restitution [9] (p. 2-3, 129-130). Yet, several politicians claim today that fast and radical restitution was necessary to create a base for the Estonian (economic) success story despite the conflicts that have remained unsolved [66] (p. 3).

The process of dissolving collective farms and establishing small-scale farms by restituting lands to previous farm owners $(140,000)$ was, quite bluntly put, an economic failure, yet initially served emotional claims of righting an historical wrong. Around the year 2000, only 22,000 family farms existed, with an average size of 28.5 ha, and still over $70 \%$ of state land was used by former state and collective farms, which had been reorganised into large agricultural companies. Household farms also existed with an average size of 4 ha using one-quarter to one-third of all agricultural land [8]. It was believed that the amount of land used by family farms has the greatest potential for growth and development' [8]. This was the ideal to strive for (compare [52]).

Today, this number has diminished by approximately $65 \%$ to less than 8000 (Table 1) for several reasons. Some of them are described above: the legislative process was too slow, it stumbled upon many tiny practicalities, the ideological and moral ideals had little to do with actual real-life opportunities and economic logic. The aim of this section is to describe other structural reasons why this process was not a smooth one and what outcomes this has today.

One of the problems was the broadening of the circle of those eligible to inherit. Despite the aims that were voiced in parliamentary discussions-to prevent further division of plots-this happened anyway. Many plots had multiple co-owners and the process of restitution became more complicated due to numerous claims. Although there were attempts in Parliament to introduce regulations that would encourage restituting land as 
larger plots, many were still restituted in 'slices' as they had been previously (see [18] for path dependency and landscape inertia).

Table 1. Number of agricultural holdings by legal form of holder (source: Statistics Estonia 2021).

\begin{tabular}{cccc}
\hline \multicolumn{2}{c}{ Natural Person } & \multicolumn{2}{c}{ Legal Person } \\
\hline $\mathbf{2 0 1 0}$ & $\mathbf{2 0 2 0}$ & $\mathbf{2 0 1 0}$ & $\mathbf{2 0 2 0}$ \\
\hline 13,504 & 7708 & 1651 & 3661 \\
\hline
\end{tabular}

* The data of 2010 have been recalculated according to the threshold used in 2020.

Besides agricultural plots, people filed applications to regain land on nature protection areas, and the (new) owners had to preserve them as such. The radial shapes (Figure 4) in the Pääsküla bog near capital Tallinn is just one such example-lands that are now situated on a nature protection area were restituted precisely in the old boundaries.

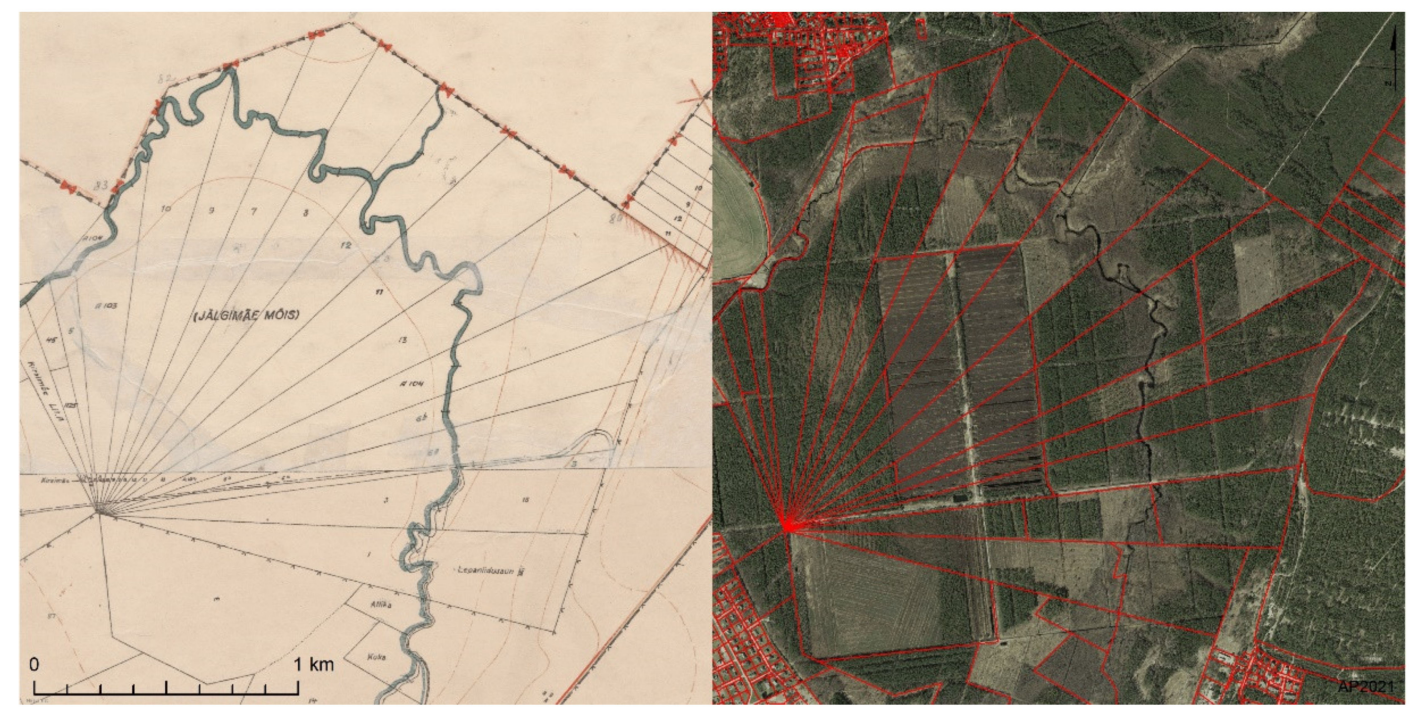

Figure 4. Map of property borders in Pääsküla bog near capital Tallinn. Männiku village, Saku municipality, Harju county (source: Cadastral map of 1930-1944, Cadastral map of 1 January 2021 based on orthophoto from 30 April 2021; Estonian Land Board 2021).

Although restitution claims were numerous, not everyone who filed a claim actually finished their restitution intentions. Many claims were withdrawn when people realised the process was too slow or required further resources-starting to build a house or cultivating land. In addition, restitution brought forth the problem of rural infrastructure: the electric and water systems needed to be restructured due to new owners and the re-bordering of plots during the Soviet era. All this contributed to slowing down the land restitution process in agricultural production, leading to its failure. It also sparked the issues of accessibility with the massive setup of private property warning signs, whereas the everyone's right, freedom to roam and coastal pathways are in use.

The Ministry of Finance [66] (p. 27), while summarising the results of the whole process, concluded that out of the 3.1 million hectares of land that had belonged to private farms in the pre-war times about half-1.52 Mha-were returned and another 1.23 Mha were used to compensate lost properties, which leaves about 0.35 Mha of land unclaimed. Hence, $60 \%$ of land in private ownership today originates from restitution and $40 \%$ from privatisation (Table 2). The biggest share of this consists of small plots (up to 2 ha) for houses and summer homes. Of all privatised units, only $11 \%$ are bigger than $10 \mathrm{ha}, 0.4 \%$ are bigger than 50 ha and $0.04 \%$ bigger than 100 ha. 
Table 2. Shares of landed property compared to the pre-war era (source: [66], p. 26).

\begin{tabular}{cccc}
\hline Ownership & $\mathbf{1 9 3 9}$ & $\mathbf{1 9 4 0 - 1 9 9 1}$ & $\mathbf{2 0 2 0}$ \\
\hline Private & $66 \%$ & 0 & $58 \%$ \\
\hline State & $33 \%$ & $100 \%$ & $41 \%$ \\
\hline Municipal & $1 \%$ & 0 & $1 \%$ \\
\hline
\end{tabular}

\section{Modern Developments}

Initially restituted land has had several developmental paths in the hands of private owners. A minority of them (see Table 1) continue as family farms. Some have sold or rented out the land for neighbours or agricultural companies (Figure 5) or kept a small piece for a summer home. During the 1990s, agricultural land was worth more than forest land, but now this is vice versa. The price of land in remote rural areas has increased more than tenfold [67], and in suburban areas even more, creating spatial inequalities. People also did not consider land tax. However, the data about land value is not up to date. Regular valuations were carried out in 1993, 1996, and 2001. A new overall land valuation is planned to be carried out by Ministry of the Environment in 2022 for the first time in 20 years. From now on, regular valuations will take place every four years, while a ceiling will be introduced to stop land tax increasing too quickly [68]. Currently, Estonia has the lowest property taxes in the European Union (EU) [69].

A new thing to learn for many was that land could be a commodity. Many people found it unjust that it is possible to buy cheap land and then sell it at a higher pricesomething that is normal in capitalism, but back then was condemned as speculation. All this led to a suspicion that not everything was done in an honest way, that connections, networks and lobbying enabled some to get better deals. Even one Minister of the Environment had to resign because he was biasedly swopping state lands into private property. This also introduced an untranslatable wordplay into the Estonian language-with just the substitution of one letter the term erastamine (privatisation) became ärastamine (meaning something like embezzlement, with ära meaning 'off').

The reason why many people went back to the countryside was an illusion that the old times would return; that people will do small-scale faming and that everything would be as romantic as it was in the past. Of course, this remained an illusion; the old countryside never returned, and people went back to towns to get jobs.

The fading of small-scale farming also reflects global dynamics in agricultural development. Since the second half of the 20th century, industrial large-scale farming has been replacing the small-scale family farm model everywhere in the Global North [70]. Implementing an economically ineffective model of small-scale farms in the context of developments within the global economy had failure written all over it at the moment of its birth.

Agricultural holdings are also subject to natural or political disturbances, such as the African swine fever virus or the Russian embargo on EU food products since 6 August 2014, influencing economic sustainability both for family farms and enterprises.

Restructuring the agricultural economy in collective farms did not necessarily go smoothly, either. Although the majority of the local collective farm workers wanted to preserve large-scale collective agricultural enterprises [64] (p. 431), the local battles to 'save' the farms in their industrial forms often failed because of the political and ideological battles fought at the state level [64]. Alanen [64] presented it as a fight between right-wing politicians, who were nostalgic about peasant society agrarian conceptions and considered collectivisation as one of the greatest crimes of socialism on the one hand, and on the other, the locals who had a pragmatic vision about the restructuring. In this ideological battle, the collective farm activists were labelled as 'byvshie [bygones]' in Russian, or 'red barons', who were responsible for the crimes of communism and, therefore, not credible in knowing the best ways of restructuring agriculture [64,71]. The reform was predominantly carried out by a narrow elite group with an urban background, proponents of a liberal 
market ideology. Thus, agricultural subsidies were removed during the toughest time, 1991-1993 [64] (p. 434). The governing liberal party stressed that agriculture, just like any other branch, should operate under free market conditions without state interference [72] (p. 7). This resulted in severe social problems and even pauperisation of some segments of the rural population by the end of the century [73]. State help arrived in the form of various EU subsidies even before Estonia's official accession in 2004 and continues still.

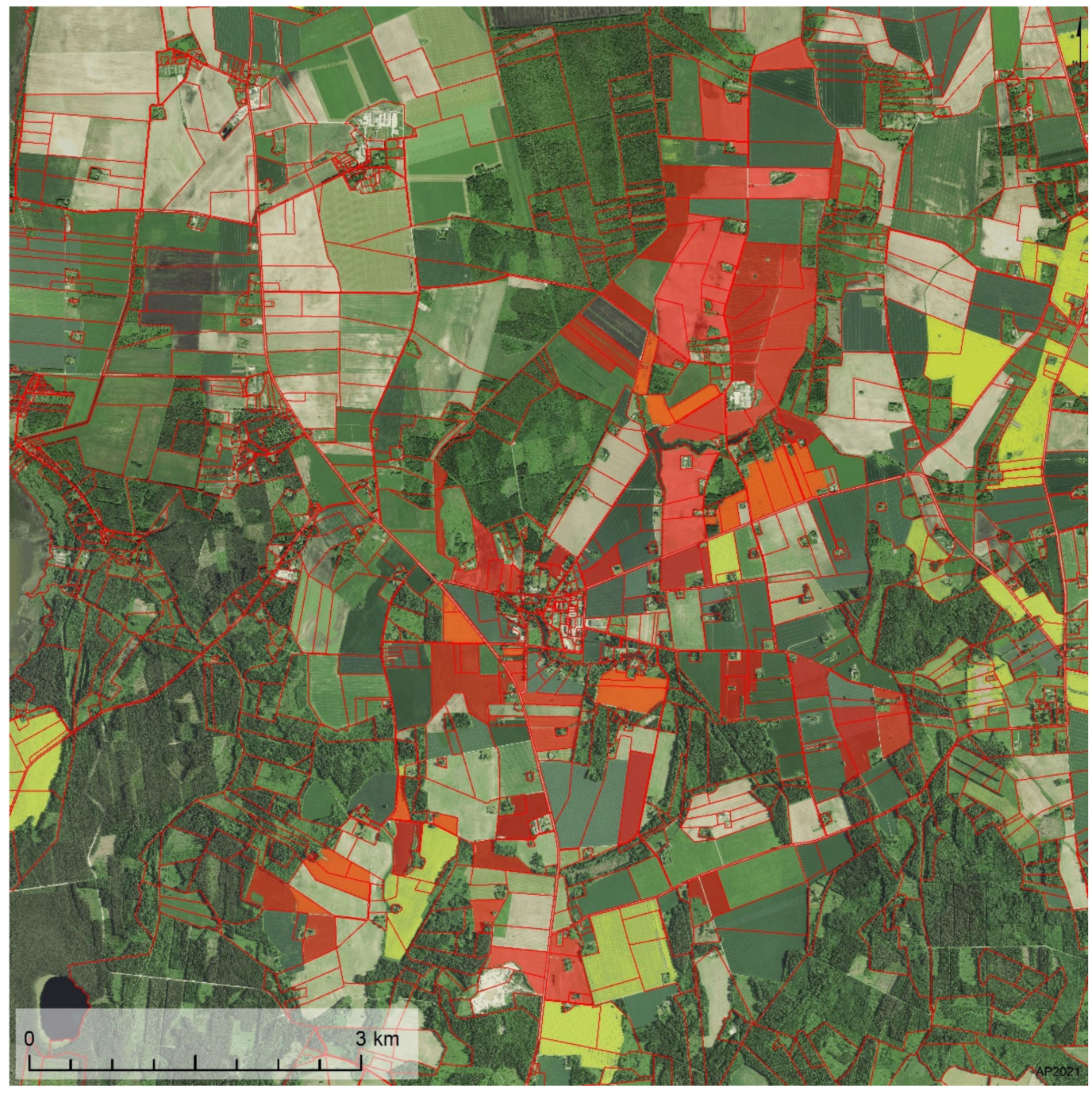

Figure 5. Properties (in semi-transparent red shades) of one of the top 200 agricultural businesses by turno-ver, Rannu Mõis [manor], in Elva municipality, Tartu county (source: Agricultural Registers and Information Board 31 December 2021, Cadastral map of 1 January 2021 based on orthophoto from 7 June 2021; Estonian Land Board 2021).

Even though restitution and de-collectivisation were the main aims of government policies, by 1996, only one-third of collective farms had been officially dissolved. This depended much on local struggles and contexts and, in some places, collective farms were reorganised and successfully privatised as large-scale agricultural ventures. Yet, in many cases the collective farms just faded away into oblivion, lacking human resources to implement the legislative ideals through formal procedures. The process of successful privatisation was not necessarily a just one-often, the previous collective farm leaders took hold of the processes and regular employers (such as Villu, whose truck was stolen in the book) were left unemployed.

Land restitution brought forth another outcome, paradoxically also one that the politicians had wanted to avoid at all costs. Back in the 1990s, it was considered highly 
immoral to sell ('speculate with') land, or to use agricultural land for other purposes besides cultivation. However, despite these concerns, soon after the restitution process had started, people started to sell restituted land that was situated close to the cities. New suburban areas developed rather quickly. Ideon [74] demonstrated that urban sprawl has closely followed existing administrative borders and infrastructure: $69 \%$ of the newly built areas are within $1 \mathrm{~km}$ of a city and $88 \%$ are located less than $1 \mathrm{~km}$ from a main road. One also notices that the pattern-the spatial arrangement of streets and plots-differs from the pattern created during Soviet times. The plots divided when land was used by collective farms have a street network that is regular and does not follow former property borders. The newer developments strictly follow the former property borders and seldom leave possibilities to connect the developed area with a neighbouring parcel [75] (Figure 6). The land reform foresaw problems occurring with road maintenance and clearing of snow, but the real issue seems to be accessibility. Earlier this was regulated by customary law, but after the restitution access from a public road to each plot should always be legally solved to avoid conflicts, court cases, and the possibility of receiving a bank loan. This has proven not to be that easy for the municipalities [75] (p. 301). The majority of municipal land consists of transportation networks [66] (p. 28).

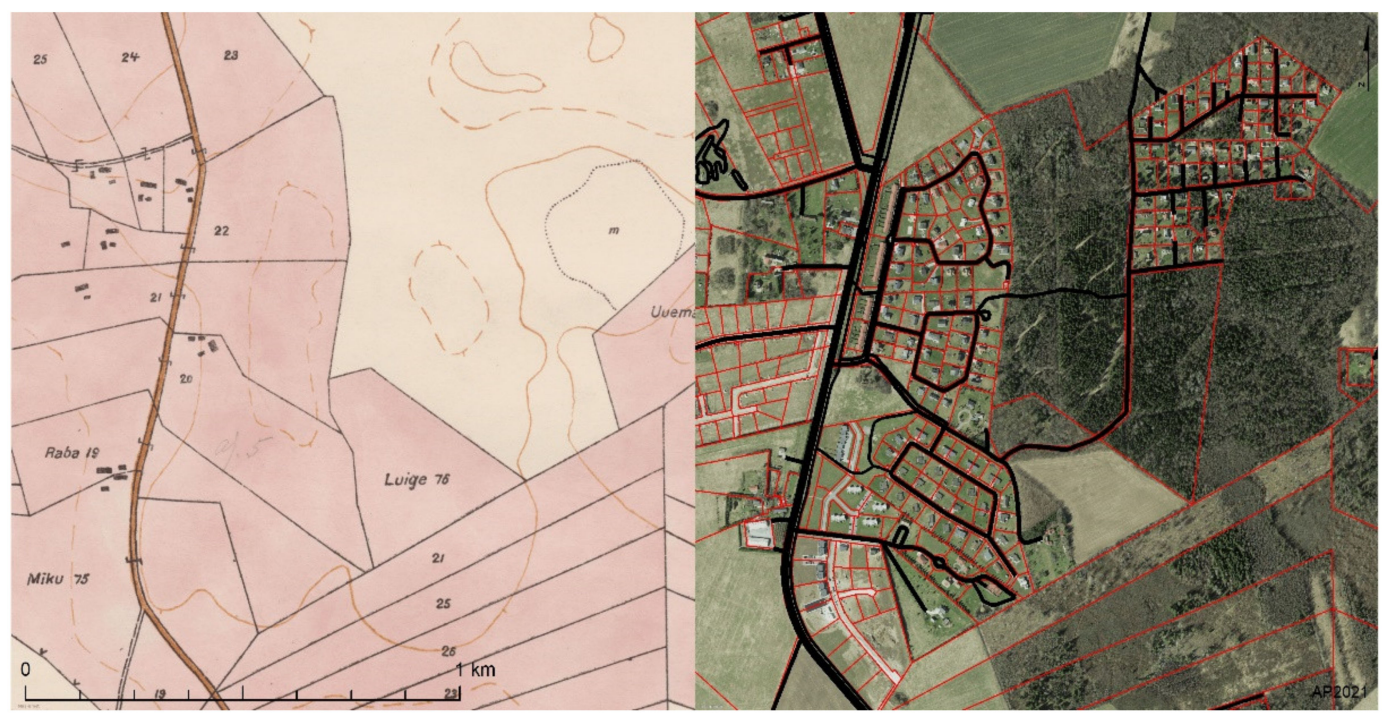

Figure 6. Map of property borders in Vaela village, Kiili municipality, Harju county, near the capital Tallinn (source: Cadastral map of 1930-1944, Cadastral map of 1 January 2021 based on orthophoto from 30 April 2021, overlaid by the road layer from the Estonian Topographic Database 1 January 2021; Estonian Land Board 2021).

This development points to two processes. One, that agriculture has become less profitable than real estate development-one of the main reasons behind (sub)urbanisation everywhere. It has become more profitable for the farmer to divide land into parcels and start growing houses instead of more traditional crops. It has roots in history-the renaturalisation of farmland was perceived by many farmers in the 1990s as abandoning the efforts of previous generations: 'Don't let land go to waste!'. Overgrowth into bushland and, consequently, into forest in the due course of natural succession on agricultural lands was perceived unfavourably [76]. Less than 30 years later, the Estonian public is concerned over too much timber cutting in state forests for the sake of preserving ecologically valuable areas [67]. As Palang and Peil [77] point out, often the farms that started selling lands were also the first ones bought for property a century ago, thereby encouraging a speculation about the centres of innovation being stable and supporting the idea of persistence of many features in the landscape, despite all political changes and struggles (see also [18,78]). 


\section{Conclusions}

Land reform was the most influential, and technically the most complicated reform, after the restoration of independence [66] (p. 26). Its implications influence everyday life in very many aspects.

First, borders and identity. Although the history of the 20th century has been anything but stable in Estonia, property borders have endured over the last one and a half centuries. Contemporary borders can be traced back to the cadastral system from the mid-19th century, when peasants started to buy land. What is most important, these boundaries also survived the 50 years of 'borderless' Soviet times. When all the land was nationalised in the 1940s, the property boundaries removed from the maps moved to people's memories. Thus, cadastral borders may act as a reference system for national identity.

Second, restitution is always much more difficult than just land reform, regardless of whether the expropriation happened suddenly or gradually. There are questions of burned archives, lost documents, family relations and many more involved in the legal processes [9]. After the initial slow start from the Farm Act (1989) with the adoption of the Land Reform Act (1991), restitution was completed on 99\% of Estonia's territory after 30 years. Whether there are any plans to call it entirely completed has not been publicly discussed.

Third, idealism. Much of the restitution revolved around the ability to cultivate the land, to be worthy of the restitution, as were the war heroes of the 1920s. There was the idea of the rural idyll of the 1930s, a 'golden' age that should come back once the restitution is over-the shared vision of an Estonian rural economy based on farms that are self-sustainable, self-reliant, and self-subsistent. However, this idyll never materialised, creating tensions and disappointment. People learned in a hard way that the past is indeed over and cannot be recovered.

Fourth, and perhaps the most important, is the question of justice and moral geographies. The reform, although 'with lots of comical and even farcical elements, but in reality, a tragedy' [64] (p. 444), was needed to restore the feeling of justice among the population. That is what a legal system is supposed to do-treat people equally; and then, the intricacies followed - the devil hides in details. At the beginning of the reform, land and property were treated much more ideologically. During the reform, this attitude changed towards a more practical one that allows selling and buying land much more easily.

Law, including customary law, is significant for the shaping of landscape; the earliest meaning of the term 'landscape' is linked to the role of legal institutions. Law and landscape are in turn both shaped by conceptions of justice, as well as by contestations over what is considered just and unjust in different societies [48] (p. 1).

The reform was painful, maybe not always just, but indeed badly needed for revising the feelings of justice and morality linked with land. The new landscape that the reform created indeed reflects new moral categories and ideology. As these two are interdependent, landscape can, in turn, mould moral ideals in certain ways.

Author Contributions: A.P.: conceptualisation, methodology, investigation, analysis, original draft preparation, writing, visualisation. R.N.: methodology, investigation, analysis, original draft preparation, writing. H.P.: analysis, writing. All authors have read and agreed to the published version of the manuscript.

Funding: This research has been supported by the Estonian Research Agency (PRG398 Landscape approach to rurbanity).

Data Availability Statement: The stenograms of the Estonian Parliament sessions that form the basis of the analysis in Section 3 are available at https:/ / stenogrammid.riigikogu.ee/et (7 February 2021). The Estonian National Museum archive is available in the museum, Muuseumi tee 2, Tartu. Statistics are available publicly from Statistics Estonia (https:/ / www.stat.ee) (22 December 2021). Maps are available publicly from the Estonian Land Board (https:/ / geoportaal.maaamet.ee) (23 December 2021) and Agricultural Registers and Information Board (https:/ / www.pria.ee) (23 December 2021).

Conflicts of Interest: The authors declare no conflict of interest. 


\section{Notes}

1 In the Soviet Union, after a person graduated university or vocational school, they were assigned to employment in different parts of a given Soviet republic, or to another part of the USSR altogether. The graduate had to work at this job for a certain number of years before they could move on. In Estonia, where the language of study in the majority of universities was Estonian, post-graduation employment assignments usually remained within Estonia, apart from certain strategic subjects (e.g. geology), especially if the student had studied in Russian.

2 The stenograms of the Estonian Parliament sessions that form the basis of this analysis are available at https://stenogrammid. riigikogu.ee/ et (accessed on 30 December 2021).

3 In Estonia, National Capital Bonds (NCB), known as 'yellow cards' after their yellow appearance, were introduced initially in 1993 to enable people to privatise their dwelling rooms. The NCBs were distributed to all permanent Estonian residents who were at least 18 years old in 1992. The value was calculated based on employment period in Estonia (1945-1992). Everybody was given NCBs for at least 10 years regardless of their actual employment years. There were certain bonus years for those politically repressed, orphans and parents. As what could be done with the NCBs was unclear, at some periods their value was very low, causing some speculative deals. The NCBs were inheritable. While initially meant for privatisation of dwellings, the bonds soon acquired wider usage and enabled all kinds of privatisation, including land and collective farms, until the end of 2006 [66] (p. 28).

\section{References}

1. Hull, S.; Babalola, K.; Whittal, J. Theories of land reform and their impact on land reform success in Southern Africa. Land 2019, 8, 172. [CrossRef]

2. Meitzner Yoder, L.S.; Joireman, S.F. Possession and precedence: Juxtaposing customary and legal events to establish Land Authority. Land 2019, 8, 126. [CrossRef]

3. Mutu, M. The Treaty Claims Settlement Process in New Zealand and its impact on Māori. Land 2019, 8, 152. [CrossRef]

4. Stubblefield, E.; Joireman, S. Law, violence, and property expropriation in Syria: Impediments to restitution and return. Land 2019, 8, 173. [CrossRef]

5. Wynyard, M. 'Not one more bloody acre': Land restitution and the Treaty of Waitangi Settlement Process in Aotearoa New Zealand. Land 2019, 8, 162. [CrossRef]

6. Tamm, M. In search of lost time: Memory politics in Estonia, 1991-2011. Natl. Pap. 2013, 41, 651-674. [CrossRef]

7. Troska, G. Eesti Külad XIX Sajandil; Eesti Raamat: Tallinn, Estonia, 1987.

8. Giovarelli, R.; Bledsoe, D. Land Reform in Eastern Europe: Western CIS, Transcaucuses, Balkans, and EU Accession Countries; Food and Agriculture Organization of the United Nations: Seattle, WA, USA, 2001. Available online: https://www.fao.org/3/ad878e/AD8 78E00.htm\#toc (accessed on 30 December 2021).

9. Terk, E.; Järvelaid, P.; Kivirähk, J.; Saar, I.; Kunitsõn, N.; Liiv, K.; Leppik, L. Omandireformi Sotsiaalsed ja Õiguslikud Mõjud; Tallinna Ülikool: Tallinn, Estonia, 2021. Available online: https://www.rahandusministeerium.ee/system/files_force/document_files/ omandireformi_uuringu_koondaruanne.pdf?download=1 (accessed on 30 December 2021).

10. Kasepalu, A. Mis Peremees Jätab, selle Mets Võtab. Maakasutus Eesti Külas; Eesti Teaduste Akadeemia: Tallinn, Estonia, 1991.

11. Mander, Ü.; Palang, H. Changes of landscape structure in Estonia during the Soviet period. GeoJournal 1994, 33, 45-54. [CrossRef]

12. Palang, H. Time boundaries and landscape change: Collective farms 1947-1994. Eur. Countrys. 2010, 2, 169-181. [CrossRef]

13. Virma, F. Maasuhted, Maakasutus ja Maakorraldus Eestis; Eesti Põllumajandusülikool, Maamõõdu Instituut, Halo: Tartu, Estonia, 2004.

14. Holt-Jensen, A.; Raagmaa, G. Restitution of agricultural land in Estonia: Consequences for landscape development and production. Nor. Geogr. Tidsskr. 2010, 64, 129-141. [CrossRef]

15. Lux, M.; Kährik, A.; Sunega, P. Housing restitution and privatization: Both catalysts and obstacles to the formation of private rental housing in the Czech Republic and Estonia. Int. J. Hous. Policy 2012, 12, 137-158. [CrossRef]

16. Kuutma, K. Who owns our songs? Authority of heritage and resources for restitution. Ethnol. Eur. 2009, 39, 26-40.

17. Valk, Ü. Ghostly possession and real estate: The dead in contemporary Estonian folklore. Folklore 2006, 43, 31-51. [CrossRef]

18. Zarina, A. Path dependence and landscape: Initial conditions, contingency and sequences of events in Latgale, Latvia. Geogr. Ann. Ser. B 2013, 95, 355-373. [CrossRef]

19. Online Estonian Encyclopedia. Available online: http://entsyklopeedia.ee/artikkel/eesti_rahvaarv (accessed on 30 December 2021).

20. Kuum, J. Teadus Eesti Põllumajanduse Arenguloos. II Osa (1918-1940). 1 Maareform; Akadeemiline Põllumajanduse Selts: Tartu, Estonia, 2003. Available online: https://agrt.emu.ee/full/2003_teadus_arenguloos.pdf (accessed on 30 December 2021).

21. Maandi, P. The silent articulation of private land rights in Soviet Estonia: A geographical perspective. Geoforum 2009, 40, 454-464. [CrossRef]

22. Palang, H.; Sooväli-Sepping, H. Are there counter-landscapes? On milk trestles and invisible power lines. Landsc. Res. 2012, 37, 467-482. [CrossRef]

23. Kurg, A. Werewolves on cattle street: Estonian collective farms and postmodern architecture. In Second World Postmodernisms; Kulic, V., Ed.; Bloomsbury: London, UK, 2019; pp. 111-127.

24. Nugin, R.; Pikner, T. Kõikudes lammutamise ja mälestise vahel: Kolhoosikeskuste arhitektuuri sotsiaalne pärand. Stud. Art Archit. 2021, 30, 9-38. 
25. Palang, H.; Paal, P. Places gained and lost. In Koht ja Paik II. Place and Location II; Sarapik, V., Tüür, K., Laanemets, M., Eds.; Eesti Kunstiakadeemia Toimetised: Tallinn, Estonia, 2002; pp. 93-111.

26. Riigi Teataja. Eesti NSV Taluseadus. Available online: https:/ / www.riigiteataja.ee/akt/107062013007 (accessed on 30 December 2021)

27. Riigi Teataja. Land Reform Act. Available online: https://www.riigiteataja.ee/en/eli/ee/Riigikogu/act/507012022006/consolide (accessed on 30 December 2021).

28. Estonian Land Board. Land Reform. Available online: https://www.maaamet.ee/en/objectives-activities/land-reform (accessed on 15 March 2021).

29. Kotka, A. (Estonian Land Board, Tallinn, Estonia). Personal communication, 23 December 2020.

30. Laine, J.P. Beyond borders: Towards the ethics of unbounded inclusiveness. J. Borderl. Stud. 2021, 36, 745-763. [CrossRef]

31. Smith, D. Moral Geographies. In Ethics in a World of Difference; Edinburgh University Press: Edinburgh, UK, 2000.

32. Olwig, K.R. The landscape of 'customary' law versus that of 'natural' law. Landsc. Res. 2005, 30, 299-320. [CrossRef]

33. Pojman, L.P. Eetika: Õiget ja Väära Avastamas; Eesti Keele Sihtasutus, Tartu Ülikooli eetikakeskus: Tallinn, Estonia, 2005.

34. Matless, D. Moral geographies. In The Dictionary of Human Geography, 5th ed.; Gregory, D., Johnston, R., Pratt, G., Watts, M., Whatmore, S., Eds.; Wiley-Blackwell-A John Wiley \& Sons, Ltd.: Chichester, UK, 2009; pp. 478-479.

35. Jackson, P. Social disorganization and moral order in the city. Trans. Inst. Br. Geogr. 1984, 9, 168. [CrossRef]

36. Cresswell, T. Moral geographies. In Cultural Geography: A Critical Geography of Key Ideas; Atkinson, D., Jackson, P., Sibley, D., Washbourne, N., Eds.; I.B. Tauris: London, UK, 2005; pp. 128-134.

37. Legg, S.; Brown, M. Moral regulation: Historical geography and scale. J. Hist. Geogr. 2013, 42, 134-139. [CrossRef]

38. Proctor, J.D.; Smith, D.M. Geography and Ethics: Journeys in a Moral Terrain; Routledge: London, UK, 1999.

39. Smith, D.M. Geography and ethics: A moral turn? Prog. Hum. Geogr. 1997, 21, 583-590. [CrossRef]

40. Birdsall, S.S. Regard, respect, and responsibility: Sketches for a moral geography of the everyday. Ann. Assoc. Am. Geogr. 1996, 86, 619-629. [CrossRef]

41. Tuan, Y.-F. Topophilia: A Study of Environmental Perception, Attitudes, and Values; Prentice-Hall: Englewood Cliffs, NJ, USA, 1974.

42. Tuan, Y.-F. The Good Life; University of Wisconsin Press: Madison, WI, USA, 1986.

43. Tuan, Y.-F. Morality and Imagination: Paradoxes of Progress; University of Wisconsin Press: Madison, WI, USA, 1989.

44. Tuan, Y.-F. Human Goodness; University of Wisconsin Press: Madison, WI, USA, 2008.

45. Sack, R.D. Homo Geographicus: A Framework for Action, Awareness, and Moral Concern; Johns Hopkins University Press: Baltimore, MD, USA, 1997.

46. Sack, R.D. The geographic problematic: Moral issues. Nor. Geogr. Tidsskr. 2001, 55, 117-125. [CrossRef]

47. Sack, R.D. A Geographical Guide to the Real and the Good; Routledge: New York, NY, USA, 2003.

48. Jones, M. Landscape, law and justice-Concepts and issues. Nor. Geogr. Tidsskr. 2006, 60, 1-14. [CrossRef]

49. Lee, R.; Smith, D.M. Geographies and Moralities: International Perspectives on Development, Justice and Place; Blackwell: Oxford, UK, 2004.

50. Matless, D. Moral geographies of English landscape. Landsc. Res. 1997, 22, 141-156. [CrossRef]

51. Soja, E.W. Seeking Spatial Justice; University of Minnesota Press: Minneapolis, MN, USA, 2010.

52. Opie, J. Moral Geography in High Plains History. Geogr. Rev. 1998, 88, 241-258. [CrossRef]

53. Feldman, M. Justice in space? The restitution of property rights in Tallinn, Estonia. Cult. Geogr. 1999, 6, 165-182. [CrossRef]

54. Nugin, R.; Palang, H. Borderscapes in landscape: Identity meets ideology. Theory Psychol. 2021, 31, 780-796. [CrossRef]

55. Jansson, A. The hegemony of the urban/rural divide: Cultural transformations and mediatized moral geographies in Sweden. Space Cult. 2013, 16, 88-103. [CrossRef]

56. Riigi Teataja. Republic of Estonia Principles of Ownership Reform Act. Available online: https://www.riigiteataja.ee/en/eli/ee/ Riigikogu/act/520122018006/consolide (accessed on 30 December 2021).

57. Omandireform 30. Available online: https://jupiter.err.ee/1608260400/omandireform-30 (accessed on 30 December 2021).

58. Harley, J.B. Deconstructing the map. Cartographica 1989, 26, 1-20. [CrossRef]

59. Talujutud Maa ja Taeva vahel. Uustalunikega. 1993. Available online: https://arhiiv.err.ee/vaata/138191 (accessed on 30 December 2021).

60. Ellujäämise Kõver. Saaremaa. 1997. Available online: https://arhiiv.err.ee/vaata/ellujaamise-kover-saaremaa/same-series (accessed on 30 December 2021).

61. Kolkareportaaž. Noarootsi. 1995. Available online: https://arhiiv.err.ee/vaata/kolkareportaaz-noarootsi (accessed on 30 December 2021)

62. Männis, R. Tagasiärastaja; Eesti Raamat: Tallinn, Estonia, 1997.

63. Annist, A. Otsides Kogukonda Sotsialismijärgses Keskuskülas. Arenguantropoloogiline Uurimus; Tallinna Ülikooli Kirjastus: Tallinn, Estonia, 2011.

64. Alanen, I. Agricultural policy and the struggle over the destiny of collective farms in Estonia. Sociol Rural. 1999, 39, 431-458. [CrossRef]

65. Rennu, T.; Kukk, I.-G.; Ots, A. Maareform 30. Artiklid ja Meenutused; Maa-Amet: Tallinn, Estonia, 2021.

66. Omandireform Eestis 1991-2021; Rahandusministeerium: Tallinn, Estonia, 2021. Available online: https:/ /www.rahandusministeerium. ee/system/files_force/document_files/omandireform_eestis_1991-2021_web_pdf?download=1 (accessed on 30 December 2021).

67. Palang, H.; Külvik, M.; Printsmann, A.; Storie, J.T. Revisiting futures: Integrating culture, care and time in landscapes. Landsc. Ecol. 2019, 34, 1807-1823. [CrossRef] 
68. News.err.ee. Land Board Starts Preparations for Land Tax Hike. Available online: https://news.err.ee/1208605/land-boardstarts-preparations-for-land-tax-hike (accessed on 30 December 2021).

69. News.err.ee. Report: Estonia Has Europe's Lowest Property Taxes. Available online: https://news.err.ee/1608365310/ reportestonia-has-europe-s-lowest-property-taxes (accessed on 30 December 2021).

70. Woods, M. Rural; Routledge: London, UK, 2011.

71. Grünberg, K. 'Nagu me ei olekski tööd teinud.' Katkestused ja järjepidevused endiste põllumajandusjuhtide omaeluloolistes jutustustes. In Maaelu ja Elu Maal Muutuste Tuultes. Põllumajandusreform 20; Kohler, V., Ed.; Eesti Põllumajandusmuuseum: Tartu, Estonia, 2014; pp. 169-194.

72. Loko, V. Current situation and perspective of Estonian agricultural policy. In Agricultural Development Problems and Possibilities in Baltic Countries in the Future. Finnish-Baltic Joint Seminar, Saku, Estonia. Research Publications 72; MTTL Agricultural Economics Research Institute: Jokioinen, Finland, 1993; pp. 7-9.

73. Unwin, T. Rurality and the construction of the nation in Estonia. In Theorizing Transition: The Political Economy of Change in Central and Eastern Europe; Pickles, J., Smith, A., Eds.; Routledge: London, UK, 1998; pp. 284-306.

74. Ideon, A. Eeslinnastumisest Tallinna Linnastus. Hoonestusalade Laienemine Aastatel 1995-2005. Master's Thesis, Institute of Geography, University of Tartu, Tartu, Estonia, 2006.

75. Lind, M.; Rennu, T. Paralleelmaailmad teede ja liinide rägastikus. In Maareform 30. Artiklid ja Meenutused; Rennu, T., Kukk, I.-G., Ots, A., Eds.; Maa-Amet: Tallinn, Estonia, 2021; pp. 289-302.

76. Kaur, E.; Palang, H.; Sooväli, H. Landscapes in change-Opposing attitudes in Saaremaa, Estonia. Landsc. Urban Plan. 2004, 67, 109-120. [CrossRef]

77. Palang, H.; Peil, T. Mapping future through the study of the past and present: Estonian suburbia. Futures 2010, 42, 700-710. [CrossRef]

78. Palang, H.; Printsmann, A.; Konkoly-Gyuró, É.; Urbanc, M.; Skowronek, E.; Woloszyn, W. The forgotten rural landscapes of Central and Eastern Europe. Landsc. Ecol. 2006, 21, 347-357. [CrossRef] 